異時性に発生した原発不明両側鼠径部リンパ節転移癌の 1 例

\begin{tabular}{|c|c|c|c|c|c|c|c|c|c|c|}
\hline & & & & 立相 & 模原: & 病院 & 犐， & 同 & 病理 * & \\
\hline & T & 徹 & 金 & 澤 & 秀 & 紀 & 西 & 山 & 保比古 & 田 悟 \\
\hline 挑 & 山 憲 & 義 & 高 & 橋 & 俊 & 毅 & 三 & 富 & & \\
\hline
\end{tabular}

異時性に発生した原発不明両側鼠径部リンパ節転移癌の 1 例を経験したので報告す る. 症例は70歳, 女性. 右鼠径部の鷄卵大の腫瘤を主訴に来院. 超音波, CT, 吸引細胞 診にて鼠径部リンパ節転移性扁平上皮癌と診断され入院. 消化器系, 泌尿・生殖器系, 皮成・外陰部などの検索を行ったが原発巣は不明であった。術前化学療法 (CDDP+5FU）にて縮小し，その後摘出手術を行った。術後右鼠径部に放射線照射（総線量60Gy） を行い, その後精查を続けるも再発や原発巣の出現を認めなかったが, 右側摘出から約 3 年 3 力月後, 対側の左鼠径部にうずら卵大の腫瘤を触知し, 超音波, CT, 吸引細胞診 にて梟径部リンパ節転移性扁平上皮癌と診断された。右側初発時と同様に全身の検索を 行ったが, 原発巣は不明であった. 速やかに摘出手術を行い, 術後左鼠径部に放射線照 射 (総線量50Gy) を行った. 左側摘出から約 2 年 5 カ月が経過したが，原発巣の出現や， 再発を認めていない.

卖引用語：鼠径部リンパ節, 原発不明リンパ節転移癌, 原発不明癌

緒言

原発不明な転移癌とは, 臨床的, 放射線診断学的, 内視鏡的に原発巣が不明なものと定義される". 今回 われわれは, 右側初発から 3 年 9 力月を経過して対側 発症した原発不明鼠径部リンパ節転移性扁平上皮癌の 1 例を経験したので報告する。

$$
\text { 症例 }
$$

患者：70歳, 女性.

主訴：右鼠径部腫瘤.

既往歴：66歳時より高血圧にて当院内科通院中. 輸 血歴なし.

家族歴：特記事項なし。

現病歴: 平成 8 年 4 月初旬, 右鼠径部に小指頭大の 発赤した腫瘤を自覚。鈍痛あり。次第に増大し鵴卵大 となったため, 同年 5 月 7 日当院初診. CT, 超音波検 査にて同所に充実性の腫瘤を認めた。吸引細胞診にて class $\mathrm{V}$, 扁平上皮癌が強く示唆され, 精查加療目的に て同年 6 月21日入院となった.

2002年 8 月20日受付 2002 年 9 月20日採用 〈所属施設住所〉

₹228-8522 相模原市桜台 $18-1$
入院時現症：身長 $158 \mathrm{~cm}$, 体重 $54 \mathrm{~kg}$. 体温 35.8 度. 栄養良好. 頭頸胸部異常なし. 腹部平坦, 肝脾腫なし。 右鼠径部に半球状に突出した $6 \mathrm{~cm} \times 4 \mathrm{~cm}$ 大の腫瘤を 認める. 皮膚は暗赤色に変色し平滑, 弾性硬で熱感は なく，皮成に固定されており移動性なし，軽度圧痛を 認めた（图 1 ）他，表在リンパ節触知せず.

入院時検查所見：軽度の盆血と HCV 抗体 $(+)$ 以 外, 異常を認めなかった. SCC が3.3ng $/ \mathrm{ml}$ と高值を示 したが，CEA，CA19-9は正常範囲であった。

超音波所見：右鼠径部に大きさ $4.0 \mathrm{~cm} \times 3.7 \mathrm{~cm} \times$ $3.7 \mathrm{~cm}$ の内部均一な low echo を示す充実性腫瘤を認 め,リンパ節と思われた（図2）。

胸部〜腹部〜骨盤 CT 所見：胸部異常なし. 腹部異 常なし. 腹水なし. 右鼠径部, 右大腿動静脈のすぐ腹 側に接し周囲との境界不明睹で不整形な $3 \mathrm{~cm}$ 大の腫 瘤を認める. 皮凨浸潤像あり, 内部は筋組織と同等の density で均一, 造影 CTにて enhance が認められた。 他, 骨盤内異常なし (図 2 ).

${ }^{67} \mathrm{Ga}$ シンチグラム所見：右鼠径部を含め, 明らかな 集積を認めず。

上部消化管内視鏡所見：食道異常なし。胃は表層性 胃炎のみ.十二指腸下行脚まで異常なし。 


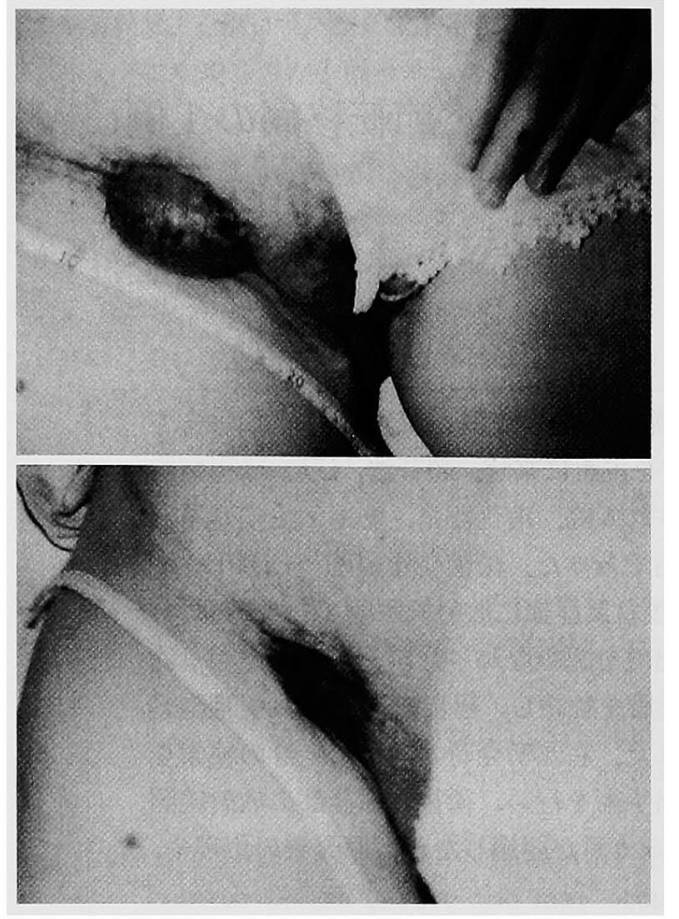

図 1 右鼠径部肉眼所見 $\frac{\text { 来院時 }}{\text { 化学療法後 }}$

バリウム注腸造影所見：異常なし.

腎昷尿管膀胱造影所見：異常なし.

尿細胞診所見 : class II.

膀胱鏡検査：異常なし.

婦人科的検査：内診異常なし。経腔超音波検査異常 なし.予宮胵部および体部内膜細胞診はともにclass II.

以上の検查成續より，原発不明右臼径部りンパ節の 転移性扁平上皮癌と診断. 腫瘤が大きく, 部位が可動 部であり，切除により機能障害が発生する恐れがあっ たため, 腫瘤の縮小を図るべく術前化学療法として平 成 8 年 7 月 2 日, CDDP $100 \mathrm{mg} /$ body 静脈内投与. 7 月 3 日から 7 月 7 日の 5 日間に5-FU 1,000mg/body/ day (total $5,000 \mathrm{mg}$ ) の静脈内投与を行った.すると, 7 月25日 (化学療法開始後23日目)には $4 \mathrm{~cm} \times 2 \mathrm{~cm}$ ま で縮小したため, 平成 8 月 7 年29日, 摘出手術を施行 した(図1).

手術所見：1\%キシロカインによる局所麻酔下，腫 瘤の辺緑から $2 \mathrm{~cm} の$ 正常な皮膚を含めた切開を行 い，皮屬と同じ範囲で皮下組織を合併切除しながら腫 瘤下縁に至る。腫瘤が大腿深部静脈の大伏在静脈分岐 部と強固に瘜着していたため,鋭的に切離して摘出した。

摘出標本所見：腫瘤の大きさは $3 \mathrm{~cm} \times 2 \mathrm{~cm} \times 2$

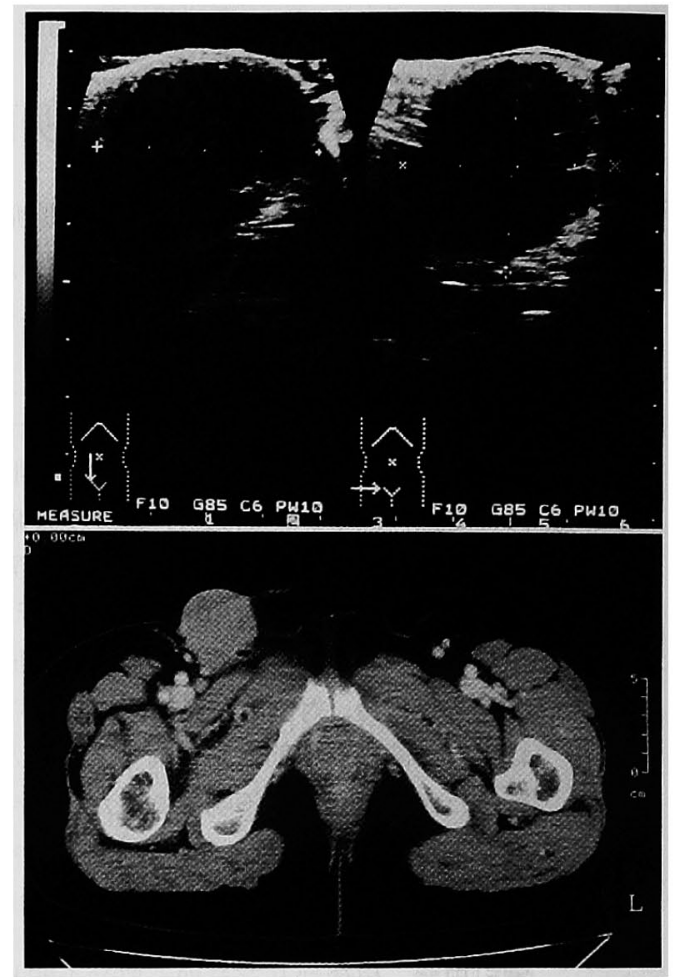

図 2 右鼠径部超音波およびCT 所見

$\mathrm{cm}$, 辺緑の境界は不明瞭. 割面は均一, 乳白色充実性 であった（図 3 )。

病理組織学的所見：摘出標本は 1 個のリンパ節で, その中には大小の異型上皮巣が島状に散見された.こ の異型上皮巣の強昖大像では敷石状に配列した多方形 の腫湟細胞がみられた. また腫瘍細胞全体の $1 / 3$ $\sim 1 / 2$ 程度に単細胞角化が認められ, 中分化型の扁平 上皮癌のリンパ節転移と診断した (図 3 ). リンパ節外 への漫潤は認められなかった。

術後経過：術後問題なく, 平成 8 年 8 月 14 日より右 舀径部に放射線照射 ( $2 \mathrm{~Gy} / \mathrm{day}$ ) を開始し, 総線量60 Gy を照射し終了した。 その後およそ 3 年 9 力月の間, 6 力月間隔で腹部 鼠径部の CT, 腹部超音波検査, 胸 部X線撮影などによる経過観察を続けるも原発巣の出 現や，再発を認めなかった。平成11年11月 1 日（右鼠 径部初発から約 3 年 9 力月, 右側摘出から約 3 年 3 力 月）来院時，左鼠径部にうずら卵大の弾性硬で圧痛の ない腫瘤を触知した(図 4). 超音波検查では大きさ3.2 $\mathrm{cm} \times 2.1 \mathrm{~cm} \times 1.4 \mathrm{~cm}$ の内部均一な low echo を示す充 奏性腫瘤を認めた。CTでは左大伏在静脈の起始部近 傍内側に大きさ約 $2 \mathrm{~cm}$ の内部均一な箭組織と同等の 


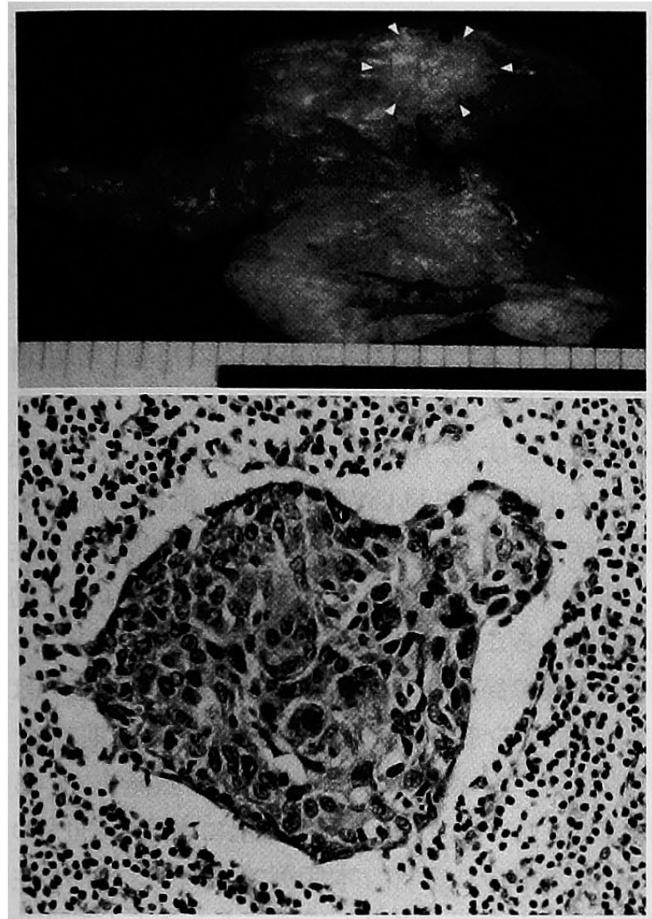

図3 右摘出標本肉眼所見および病理組織所見（H. E.染色 $\times 300$ )
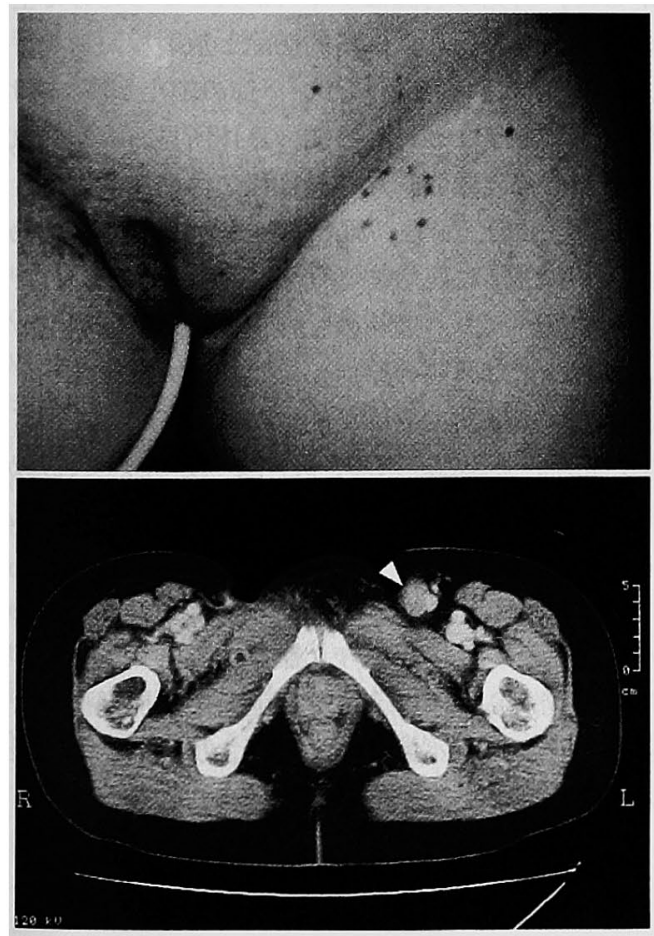

図 4 左鼠径部再発時肉眼所見および CT 所見

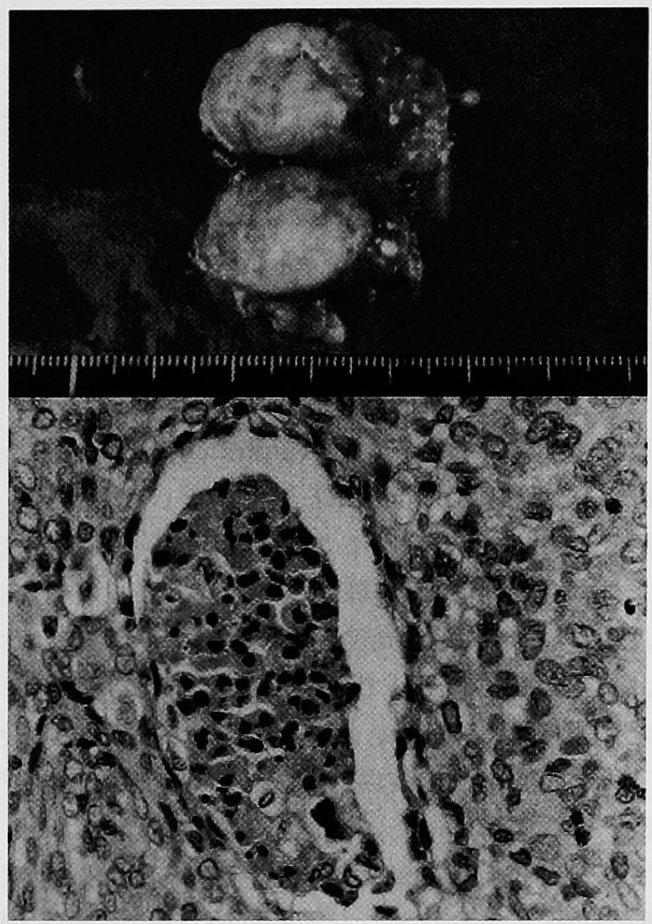

図 5 左摘出標本肉眼所見および病理組織所見 (H. E. 染色 $\times 380)$

densityで，造影 CTにて enhance れれる mass 認 めた (図 4)，吸引細胞診を実施したところ class Vで 扁平上皮癌が強く示唆され，対側リンパ節再発と診断 し，平成12年 1 月 7 日，再入院となった。前回と同様, 消化器系, 泌尿・生殖器系, 皮䖉・外陰部などの検索 を行ったが原発巣は不明であった. SCC は $0.5 \mathrm{ng} / \mathrm{ml}$ 以下で基準㯰であった。平成12年 1 月 11 日, 摘出手術 を施行した。

手術所見：1\%キシロカインによる局所麻酔下，皮 盧の合併切除は行わず，皮店を切開し，皮下脂肪層を 分けると，うずら卵大に腫大したリンパ節が認められ た。外側は大伏在静脈との強い癒着が認められ，直接 浸潤の可能性があったため大伏在静脈を $3.5 \mathrm{~cm} に わ$ たり合併切除した。

摘出標本所見：腫瘤は大きさ $2.5 \mathrm{~cm} \times 2.5 \mathrm{~cm} \times 2.0$ $\mathrm{cm}$. 割面は充実性で, 中心部 $(1.5 \mathrm{~cm} \times 1.5 \mathrm{~cm} \times 1.0 \mathrm{~cm}$, 黄白色）と辺緑部（淡桃白色）の境界明瞭な二重構造 を呈していた（図５）。

病理組織学的所見：摘出標本は 1 個のリンパ節で, 右側と同様，その中に多発する中分化型扁平上皮癌の 転移巣を認めた(図 5 )。リンパ節外への浸潤は認めら 
れず，切除断端は癌陰性であった。

術後経過：術後問題なく，平成 12 年 2 月 8 日より左 鼠径部に放射線照射 ( $2 \mathrm{~Gy} / \mathrm{day})$ を開始し, 総線量50 Gy を照射し終了した. その後, 12 力間隔で胸部〜腹 部〜鼠径部の CT, 腹部超音波検査などによる経過観 察を続けるも, 平成 14 年 5 月末日現在 (右鼠径部初発 加ら約 6 年 2 力月, 左鼠径部再発加ら約 2 年 7 力月) 原発巣の出現や, 再発を認めていない。

\section{考 察}

我が国では，原発不明癌 (unknown primary cancer）を一つの臨床単位とする認識がそしく, 報告も少 ない2). Lortholary ら"による原発不明癌311例の検討 によれば,その発生頻度はすべての成人の腫場中 $1.6 \%$ で,うち発生部位が孤発性のものは,リンパ節では72.9 \%, 骨では35.5\%, 肝では19.4\%,肺では16.5\%であ った. 組織型の頻度は, 腺癌が164例 $(52.7 \%)$ で最も 多く, ついで扁平上皮癌 90 例 (28.9\%), 未分化癌 27 例 (8.7\%)の順であった。 また, 平均生存期間は約 9 力 月であった。森永ら ${ }^{3)}$ 報告では, 生検の時点で臨床的 に原発不明とされたリンパ節転移癌の部位別発生頻度 は, 頸部が $40.6 \%$ と最も多く，ついで鎖骨上窩 $28.1 \%$, 縌隔9.4\%, 鼠径部9.4\%, 腋窩 $6.3 \%$, 腹部 $6.3 \%$ の順 であった。

一般診療におけるリンパ節転移癌の診断は, リンパ 行性転移の原則に基づき, リンパ路の上流にあたる蔵 器から原発巣の検索を始めるのが定石である2!。しか し, 乳癌の瓦径部リンパ節転移》や, 前立腺癌の頸部り ンパ節転移516)など, 通常のリンパ流からは説明のつか ない例外的な転移例も報告されており, 腋筒や鼠径部 のように, 比較的リンパの上流の臓器が限られている 場合でも, 予想される臓器に原発巣が見いだされない 場合があるので注意が必要である.また, 頸部リンパ 節内および膵周囲のリンパ節内に, 扁平上皮に裹打ち された良性䧶胞 (benign lymphoepithelial cyst) が存

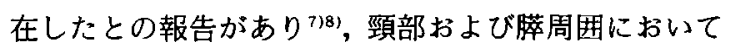
はリンパ節原発の扁平上皮癌も否定できないと考えら れ，診断には注意を要する。

一般には鼠径部リンパ節転移癌において原発不明は 稀とされ, 原発巣としては外陰部, 䐋, 子宮, 肛門部, 下肢, 躯幹に見いだされることが多く, 組織型として は扁平上皮癌やメラノーマが多い2!.

原発不明リンパ節転移癌の診断・治療の手順として は，まず初めにリンパ節の吸引細胞診や生検により癌 の組織型の検索を行う ${ }^{29110)}$. 転移リンパ節の部位, 組
織型，腫湯マーカーなどにより原発巣の検索範囲をあ る程度絞り込むことができるからである゙．また兔疫 組織学的検索により, 前立腺癌(酸フォスファターゼ, 前立腺特異抗原を証明), 肧細胞性腫場 ( $\beta$-hCG, $\alpha-\mathrm{FP}$ を証明), 肝細胞癌 ( $\alpha-\mathrm{FP}$ を証明), リンパ腫および形 質細胞腫(単クローン性免度グロブリンを証明), 乳癌 （エストロゲン，プロゲステロンの受容体を証明）な どを鑑別できる ${ }^{9)}$. 電子顕微鏡による組織の微細構造 の検索も原発巣の同定に有効とされる ${ }^{9120}$.さらに, 治 療に反応しやすく，根治を期待できるような次に述へ るような疾患群を見いだすために生検は有効であ

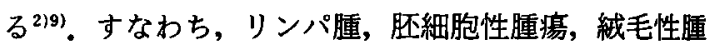
瘍, 神経内分泌腫腸などは全身化学療法によって効果 的に治療することができる ${ }^{2199}$.また，本症例のように 扁平上皮癌で局所のリンパ節に限局しているものは， 摘出と局所の放射線治療で長期生存が期待でき $ろ^{2199 .}$.メラノーマで局所のリンパ節に限局しているも のは stage IIであり,リンパ節摘出によって, 30\%の 5 年生存率が得られる ${ }^{299}$. 本症例では, リンパ節の生検 を行い癌の組織型が扁平上皮癌であることが判明した ので, 扁平上皮癌の頻度が高い子宮頸癌, 外陰部癌, 肛門癌などを中心に検索を行ったが原発巣は検出でき なかった。初発の右側はサイズが大きかったので全身 的化学療法を先行し，外科的切除と放射線照射を行っ た。化学療法によって転移リンパ節の縮小が認められ， 右側切除後 3 年 9 力月もの間, 身体所見扝よび画像診 断上原発巣の出現やリンパ節転移の再発兆候がみられ なかったことから, 原発巣に対して complete response (CR) に匹敵する効果があったと思われた。 また, 鼠径部リンパ節への転移再発が対側に発生した ことから，未だ不明の原発部位は両側の鼠径部リンパ 節が所属する缄器である可能性が高く, 子宮, 子宮付 属器, 膀脱, 外陰部, 直腸, 肛門などが考えられたが, 原発巣は検出されていない. 今後も原発巣抽よび鼠径 部リンパ節の定期的かつ厳重な検索が必要であると考 えている。

\section{結 語}

右側初発から 3 年 9 カ月を経過して対側発症した原 発不明鼠径部リンパ節転移性扁平上皮癌の 1 例を経験 したのて, 若干の文献的考察を加え報告した。 


\section{文献}

1) Lortholary A, Abadie Lacourtoisie $S$, Guerin $O$, et al: Cancers of unknown origin: 311 cases. Bull Cancer 88:619-627, 2001

2）古江 尚：原発不明癌の臨床. 癌と化療 $25: 1$ $-6,1998$

3）森永正二郎，折笠英紀：リンパ節の原発不明（転 移性) 癌の病理診断. 病理と臨 $18: 1160-1166$, 2000

4) Baba M, Tatsuta M, Miya A, et al: A case of breast cancer diagnosed by inguinal lymph node metastases. Breast Cancer $7: 173-175$, 2000

5）万代光一，森脇昭介，佐伯俊昭他：リンパ節転移 性腫瘍の臨床病理学的検討, 原発不明癌と関連し て。 日癌治療会誌 $29: 978-989,1994$

6）久末伸一，高木良雄，赤樫圭吾 他：頸部リンパ節
転移により発見された前立腺癌の 2 例. 臨泌 $52: 671-673,1998$

7) Hong SS, Ogawa $Y$, Yagi $T$, et al:Benign lymphoepithelial lesion with large cyst: case report. J Oral Pathol Med 19:266-270, 1990

8) Sako $S$, Isozaki $H$, Hara $H$, et al: Cystic lymphoepithelial lesions of the pancreas and peripancreatic region: report of two cases. Surg Today 29:467-471, 1999

9) Oken MM : 原発栄不明の転移性癌, 癌化学療法 ハンドフック第 3 版（古江 尚, 田口鐵男, 仁井 谷久暢他訳)，メディカル・サイエンス・インター ナショナル社, 東京, 1996, p259-263

10) Dodion P, De Valeriola D : Diagnosis and treat. ment of unknown primary tumors. Bull Cancer $76: 939-946,1989$

\title{
A CASE OF HETEROCHRONOUSLY OCCURRED BILATERAL INGUINAL LYMPH NODE METASTASES OF UNKNOWN ORIGIN
}

\author{
Toru KIMURA, Hideki KANAZAWA, Yasuhiko NISHIYAMA, Goro KANEDA, \\ Noriyoshi AKIYAMA, Toshitake TAKAHASHI and Hiroyuki MITOMI* \\ Departments of Surgery and Pathology*, National Sagamihara Hospital
}

\begin{abstract}
We report a case of heterochronously occurred bilateral inguinal lymph node metastases of unknown origin.

A 70-year-old woman was seen at the hospital because of a right inguinal tumor with the size of an egg. With ultrasonography, CT, and aspiration biopsy cytology, metastatic squamous cell carcinoma of the inguinal lymph nodes was diagnosed and the patient was admitted to the hospital. Primary lesion was obscure despite explorations of the gastrointestinal tract, urinary/genital organs, skin, and external genitalia. After the tumor was reduced by preoperative chemotherapy with $\mathrm{CDDP}+5-\mathrm{FU}$, it was surgically removed. Radiation therapy at a total dose of $60 \mathrm{~Gy}$ was given to the right inguinal region after the operation. The patient was strictly followed and had experienced no recurrence and appearance of primary lesion until approximately 3 years 3 months after the operation, when she felt a left inguinal tumor with the size of a quail egg. Metastatic squamous cell carcinoma of the inguinal lymph nodes was diagnosed with ultrasonography, CT, and aspiration biopsy cytology. In spite of the same systemic exploration as we conducted for the cotralateral lesion, primary lesion was still unknown. Immediately the patient underwent a removal of the tumor, followed by irradiation at a total dose of $50 \mathrm{~Gy}$ for the left inguinal region. There have been no emergence of primary lesion or signs of recurrence, as of about 2 years 5 months after the removal of the left inguinal lesion.
\end{abstract}

